\title{
Uveitis outcome and complication
}

\author{
Ivan Foeldvari \\ From 21st European Pediatric Rheumatology (PReS) Congress \\ Belgrade, Serbia. 17-21 September 2014
}

Anterior uveitis is a well-known threatening comorbid condition of JIA and affects around 10 to $20 \%$ of the patients depending on JIA subtype. A large proportion of children with JIA develop uveitis in the first year of disease and 73 to $90 \%$ do so after four years of the arthritis onset. Uveitis can progress into the adulthood and usually occur as "white uveitis" which is not associated with symptoms like redness and pain as opposed to JIA related to the enthesitis subtype that is symptomatic. Factors associated to lower uveitis remission rate are: JIA diagnosis, findings of $1+$ or more vitreous cells at presentation and initial visual acuity of 20/200 or worse. The Standardization of Uveitis Nomenclature (SUN) Group took the first step to define outcome measures for uveitis, but it was established just for adults. The Multinational Interdisciplinary Working Group for Uveitis in Childhood (MIWGUC) proposed outcome measures for JIA associated uveitis incorporating the Standardization of Uveitis Nomenclature (SUN) criteria in 2011.

\section{Disclosure of interest}

None declared.

Published: 17 September 2014

Submit your next manuscript to BioMed Central and take full advantage of:

- Convenient online submission

- Thorough peer review

- No space constraints or color figure charges

- Immediate publication on acceptance

- Inclusion in PubMed, CAS, Scopus and Google Scholar

- Research which is freely available for redistribution 